\title{
Urticaria multiforme: a benign frightening rash
}

\author{
Mariana Barros 두, Joana Antunes, Sofia Moura Antunes, Rita Calado
}

Department of Pediatrics, Hospital de Cascais, Dr José de Almeida, Cascais, Alcabideche, Portugal

\section{Correspondence to Dr Mariana Barros; marianaantunesbarros@gmail. com}

Accepted 13 January 2021

Check for updates

(C) BMJ Publishing Group Limited 2021. No commercial re-use. See rights and permissions. Published by BMJ.

To cite: Barros M, Antunes J, Moura Antunes S, et al. BMJ Case Rep 2021;14:e241011. doi:10.1136/bcr-2020241011

\section{DESCRIPTION}

We report the case of a previously healthy 13-month-old boy who developed transient, annular and erythematous wheals with dusky centres affecting the face, trunk and limbs, associated with pruritus, non-pitting oedema of upper and lower extremities and dermographism (figure 1). The rash spared palms and soles and disappeared with digital pressure and it had started 7 days after immunisation for measles-mumps-rubella, meningococcal type $\mathrm{C}$ and pneumococcal conjugate vaccine. The child was haemodynamically stable, had good overall condition and no other symptoms besides a low fever and an otherwise normal physical examination without the presence of petequiae or purpura, acute respiratory distress, laryngoedema, angioedema, lymphadenopathy, hepatosplenomegaly, arthralgia or mucous membranes involvement.

Due to the presence of a dusky ecchymotic rash in a febrile child on admission, laboratory tests were requested to rule out severe causes that could need specific immediate treatment, such as severe bacterial infections, like sepsis and coagulation disorders. Laboratory investigation revealed normal coagulation tests, platelet and white cell count as well as a slightly elevated $\mathrm{C}$ reactive protein of $2,04 \mathrm{mg} / \mathrm{dL}$ (reference range: $\leq 1 \mathrm{mg} / \mathrm{dL}$ ). Due to the presence of pruritus, an oral $\mathrm{H} 1$ antihistamine (hydroxyzine) was prescribed and cutaneous lesions progressed in an evanescent manner, with each lesion lasting less than 24 hours. There was complete resolution of symptoms within 4 days, showing no cutaneous sequelae.

Based on clinical grounds, due to the presence of pruritus and the progression of lesions in as evanescent manner during hospital stay, and the resolution without cutaneous scaring, the diagnosis of urticaria multiforme was made. The authors present this case to raise awareness for a rarer morphological presentation of a common disease.

Urticaria multiforme, a morphological subtype of acute urticaria, is a benign cutaneous hypersensitivity reaction. ${ }^{1}$ It commonly affects children between 4 months and 4 years of age and its most known triggers are infections, immunisations and medications. $^{2-4}$

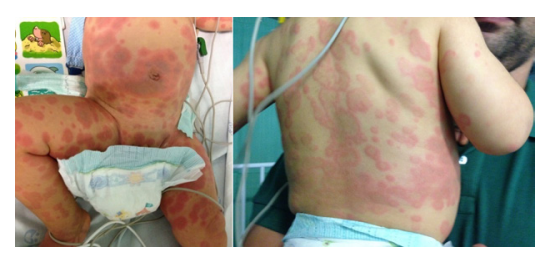

Figure 1 Annular and erythematous wheals with dusky centres affecting the trunk and limbs.
Skin lesions start with papules that expand to form annular, polycyclic, erythematous wheals with dusky, ecchymotic centres affecting the trunk, extremities and face. ${ }^{13}$ Face and extremities oedema, pruritus and dermographism are also present in most patients. Children present an non-toxic appearing and systemic symptoms are commonly limited to a few days of mild fever. ${ }^{3-6}$ In addition to presenting all the characteristic features of this disease on examination, our patient met the age range for this condition as well as a known common trigger like recent immunisations.

Urticaria multiforme is commonly misdiagnosed for erythema multiforme, serum sickness-like reaction, urticarial vasculitis, among others, despite being more frequent than the previous conditions. ${ }^{1}$

However, true target lesions, skin necrosis, blistering and mucous membrane involvement, usually present in erythema multiforme, were absent in our case as well as in urticaria multiforme cases. ${ }^{6}$ Pruritus is characteristic of urticaria multiforme, while pain and burning are present in erythema multiforme or urticarial vasculitis. ${ }^{3}$ Dermographism is absent in patients with erythema multiforme or serum sickness-like reactions and in the latter, there is prominent fever, myalgias, arthralgias and lymphadenopathy, none of which was present in our patient. ${ }^{1-3}$ In erythema multiforme, serum sickness-like reactions or urticarial vasculitis skin lesions are fixed and last days to weeks, resolving with postinflammatory depigmentation, contrary to the migratory progression and the absence of skin lesions after resolution presented by our case, corroborating the diagnosis urticaria multiforme. ${ }^{3}$ In acute haemorrhagic oedema of infancy, a small-vessel leucocytoclastic vasculitis, there are target-like or cockade appearance plaques, red to purpuric lesions with a necrotic or bullous centre that appear predominately over the ears, cheeks and extremities. ${ }^{7}$ Unlike urticaria, the colour of lesions usually changes from red or purple to brownish yellow before complete resolution. ${ }^{8}$ Our patient presented with dusky lesions, but there were no target appearance and they progressed in a migratory manner. Furthermore, there were no colour changes and lesions were present predominantly on the trunk and not in the face. The presence of pruritus and dermographism also helped differentiate these two entities. Lastly, erythema marginatum, a characteristic rash of rheumatic fever, is non-painful, transient, migrant, but unlike urticaria multiforme, it is rarely pruritic and never appears on the face. ${ }^{7}$

Laboratory tests or other interventions (ie, skin biopsy) are generally not required for the diagnosis of urticaria multiforme. However, in our case, they were requested to rule out other more severe 
conditions. An elevation in acute phase reactants may be seen in some patients with urticaria multiforme. ${ }^{15}$

Urticaria multiforme is a self-limited, benign, condition. Treatment may include discontinuation of any known precipitating factors and antihistamine therapy. In severe cases, systemic corticosteroids may be prescribed.

\section{Learning points}

- Urticaria multiforme is a subtype of acute urticaria in children, commonly linked to viral infections, medications and immunisations.

- Urticaria multiforme can be correctly diagnosed based on clinical grounds, not requiring extensive aetiological investigation.

- When faced with cutaneous lesions with dusky centres and acral angioedema, the presence of good overall condition, pruritus, dermographism and rapid response to antihistamines, in the absence of signs or symptoms of systemic disease as well as an evanescent progression with resolution without scaring, supports the diagnosis of urticaria multiforme.

Contributors MB, JA, SMA and RC were all present in the daily approach and management of the patient to whom the case report refers to. RC and SMA plannedand conducted the initial design of the present case report, pointing out the mainbullet points to transmit as well as relevant references to cite. MB and JA thenproceeded with acquisition and analysis of data regarding the case as well as additional research concerning urticaria multiforme reports and drafted the initial manuscript. RC and SMA then revised the work. All authors approved the final version.

Funding The authors have not declared a specific grant for this research from any funding agency in the public, commercial or not-for-profit sectors.

Competing interests None declared.

Patient consent for publication Parental/guardian consent obtained.

Provenance and peer review Not commissioned; externally peer reviewed.

\section{ORCID iD}

Mariana Barros http://orcid.org/0000-0002-4151-1400

\section{REFERENCES}

1 Shah KN, Honig PJ, Yan AC. "Urticaria multiforme": a case series and review of acute annular urticarial hypersensitivity syndromes in children. Pediatrics 2007;119:e1177-83.

2 Guerrier G, Daronat J-M, Deltour R. Unusual presentation of acute annular urticaria: a case report. Case Rep Dermatol Med 2011;2011:1-3.

3 Emer JJ, Bernardo SG, Kovalerchik 0, et al. Urticaria multiforme. J Clin Aesthet Dermatol 2013:6:34-9.

4 Maynard K. Urticaria multiforme: a case study. J Dermatol Nurses Assoc 2018;10:275-6.

5 Douvoyiannis M, Khan FS. Visual diagnosis: a rash that changes shape. Pediatr Rev 2015:36:e5-7.

6 Yon A, Fernandes D, Pike M. Acute anular urticaria in a child. West London Med J 2013:5:1-5.

7 Minasi D, Manti S, Chiera F, et al. Acute urticaria in the infant. Pediatr Allergy Immunol 2020;31:49-51.

8 Serra E Moura Garcia C, Sokolova A, Torre ML, et al. Acute hemorrhagic edema of infancy. Eur Ann Allergy Clin Immunol 2016;48:22-6.

Copyright 2021 BMJ Publishing Group. All rights reserved. For permission to reuse any of this content visit

https://www.bmj.com/company/products-services/rights-and-licensing/permissions/

BMJ Case Report Fellows may re-use this article for personal use and teaching without any further permission

Become a Fellow of BMJ Case Reports today and you can:

- Submit as many cases as you like

- Enjoy fast sympathetic peer review and rapid publication of accepted articles

- Access all the published articles

Re-use any of the published material for personal use and teaching without further permission

\section{Customer Service}

If you have any further queries about your subscription, please contact our customer services team on +44 (0) 2071111105 or via email at support@bmj.com.

Visit casereports.bmj.com for more articles like this and to become a Fellow 